\title{
Organic geochemical and palynological studies of the Maastrichtian source rock intervals in Bida Basin, Nigeria: implications for hydrocarbon prospectivity
}

\author{
Olusola J. Ojo ${ }^{1}$ (i) $\cdot$ Ayoola Y. Jimoh ${ }^{2} \cdot$ Juliet C. Umelo ${ }^{3} \cdot$ Samuel O. Akande ${ }^{3}$
}

Received: 15 May 2020 / Accepted: 24 August 2020 / Published online: 2 September 2020

(c) The Author(s) 2020

\begin{abstract}
The Patti Formation which consists of sandstone and shale offers the best potential source beds in the Bida Basin. This inland basin is one of the basins currently being tested for hydrocarbon prospectivity in Nigeria. Fresh samples of shale from Agbaja borehole, Ahoko quarry and Geheku road cut were analysed using organic geochemical and palynological techniques to unravel their age, paleoecology, palynofacies and source bed hydrocarbon potential. Palynological data suggest Maastrichtian age for the sediments based on the abundance of microfloral assemblage; Retidiporites magdalenensis, Echitriporites trianguliformis and Buttinia andreevi. Dinocysts belonging to the Spiniferites, Deflandrea and Dinogymnium genera from some of the analysed intervals are indicative of freshwater swamp and normal sea conditions. Palynological evidence further suggests mangrove paleovegetation and humid climate. Relatively high total organic carbon TOC (0.77-8.95 wt\%) was obtained for the shales which implies substantial concentration of organic matter in the source beds. Hydrocarbon source rock potential ranges from 0.19 to $0.70 \mathrm{mgHC} / \mathrm{g}$.rock except for a certain source rock interval in the Agbaja borehole with high yield of $25.18 \mathrm{mgHC} / \mathrm{g}$.rock. This interval also presents exceptionally high HI of $274 \mathrm{mgHC} / \mathrm{g}$.TOC and moderate amount of amorphous organic matter. The data suggests that in spite of the favourable organic matter quantity, the thermal maturity is low as indicated by vitrinite reflectance and $T_{\max }$ ( 0.46 to $0.48 \mathrm{Ro} \%$ and 413 to $475{ }^{\circ} \mathrm{C}$, respectively). The hydrocarbon extracts show abundance of odd number alkanes $\mathrm{C} 27-\mathrm{C} 33$, low sterane/hopane ratio and $\mathrm{Pr} / \mathrm{Ph}>2$. We conclude that the source rocks were terrestrially derived under oxic condition and dominated by type III kerogen. Type II organic matter with oil and gas potential is a possibility in Agbaja area of Bida Basin. Thermal maturity is low and little, or no hydrocarbon has been generated from the source rocks.
\end{abstract}

Keywords Sterane $\cdot$ Agbaja $\cdot$ Mangrove $\cdot$ Spiniferites $\cdot$ Kerogen

\section{Introduction}

The present study is focused on the source rock intervals of Patti Formation in the inland Bida Basin of Nigeria (Fig. 1). Bida Basin is of rift origin and filled with about 3.5-kmthick, flat lying upper Cretaceous clastic sediments, and they

Olusola J. Ojo

olusola.ojo@fuoye.edu.ng

1 Department of Geology, Federal University Oye Ekiti, Oye-Ekiti, Ekiti State, Nigeria

2 Department of Geology and Mineral Sciences, Kwara State University, Malete, Kwara State, Nigeria

3 Department of Geology and Mineral Sciences, University of Ilorin, Ilorin, Kwara State, Nigeria are relatively unexplored in term of petroleum prospectivity (Udensi and Osazuwa 2004). In spite of the fact that no serious hydrocarbon exploratory work has been carried out in the basin, it has often been conveniently classified as one of the marginal fields or frontier hinterland basins by the relevant government agencies. Also there have been pocket of investigations by researchers on the source rock characteristics of the Patti Formation (Obaje et al. 2004; Akande et al. 2005; Ehinola et al. 2005). However, most of these studies were based on samples obtained from road cut exposures which had been subjected to subaerial weathering over a long time. The present work has taken the advantage of the newly available core samples from Agbaja ( $7^{\circ} 56.55^{\prime}$; $\mathrm{N} 6^{\circ} 39.40^{\prime} \mathrm{E}$, northwest of rivers Benue and Niger confluence) and a recent quarry at Ahoko $\left(8^{\circ} 14.45^{\prime} \mathrm{N} ; 6^{\circ} 39.40^{\prime} \mathrm{E}\right.$, northeast of rivers Benue and Niger confluence). It is 
Fig. 1 Geological map of the study area and location of the investigated samples. Inset shows the position of Bida Basin in Nigeria

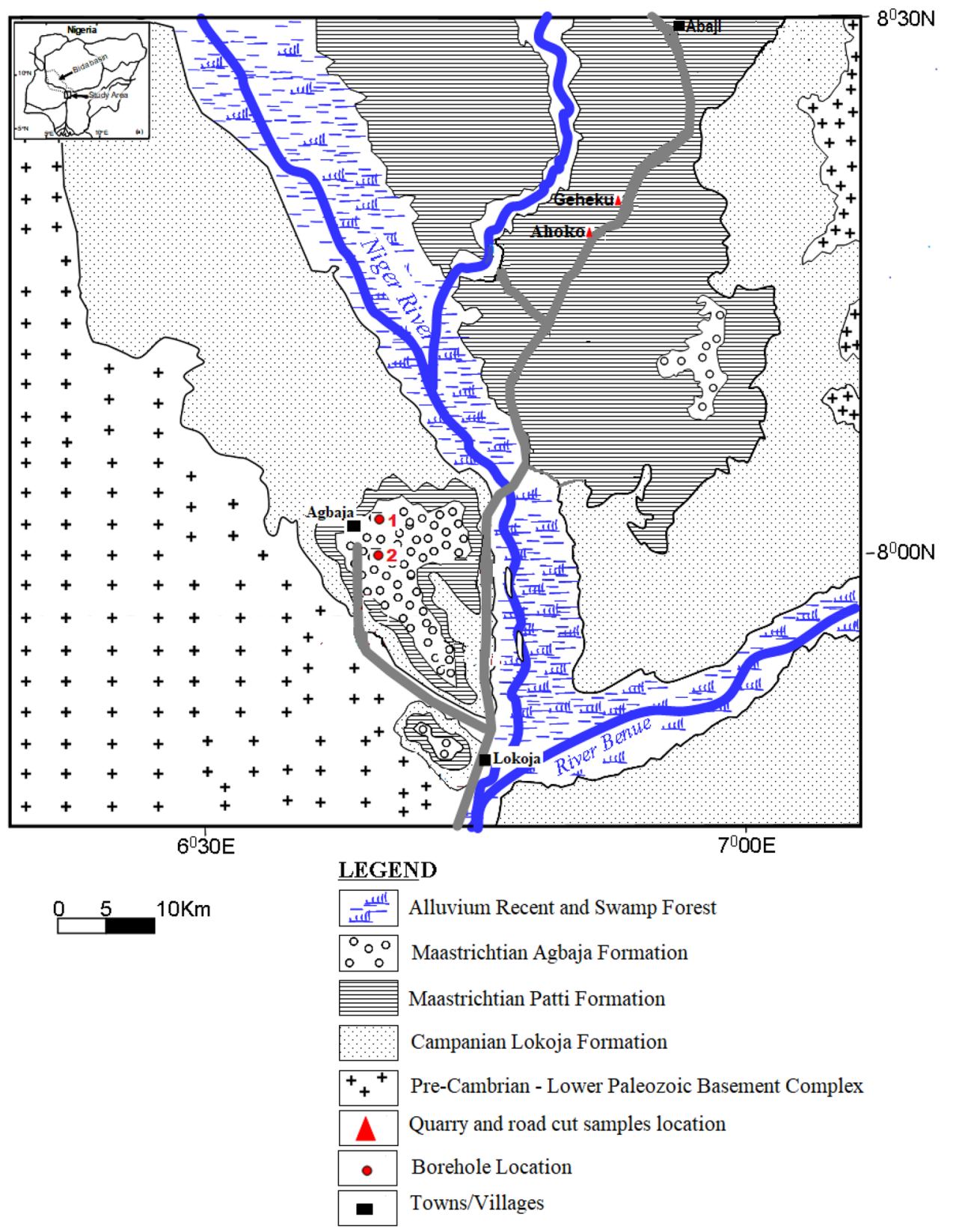

important to mention that there has never been any reported occurrence of shale lithology at Agbaja. The clastic sequence at Agbaja section in all the relevant studies was documented and described as consisting of conglomerates, sandstone, claystone and ironstone (Ladipo et al. 1994; Ojo and Akande 2009; Rahaman et al. 2019). Therefore, the discovery of shale beds and recovery of fresh subsurface shale samples during exploratory core drilling at Agbaja afford the present work the opportunity to further expand the frontier of knowledge of the source rocks and their correlative potential with those exposed in Ahoko area and determination of the source intervals that are most prospective in the basin. The organic contents of sediment and the composition of oil in the charged reservoir depend on accumulation of organic matter, the environment that preserve large amount of organic matter, burial and diagenesis of organic matter till hydrocarbon generation. The concept of source rock and petroleum charge system is strategic for petroleum exploration particularly in a virgin or marginal field like Bida Basin. The age of the source beds, paleodepositional environments, paleoredox condition, type and maturity of the organic matters are investigated in this study. This is expected to provide platform for more baseline data and advance detail source rock potential evaluation in view of on-going interest of the Federal Government in testing petroleum potential of inland basins in Nigeria and the overarching goal of discovering 
commercial hydrocarbon plays in the in land basins. Exploration for hydrocarbon in a frontier basin like this requires deep understanding of the stratigraphy and depositional environments of the sedimentary succession, while realistic prediction of the source rocks depends on accurate reconstruction of their depositional and burial history. Given this scenario, knowledge of the source rock characteristics and stratigraphy would assist in hydrocarbon prospecting. This present work is also significant because new organic geochemical and palynological data are generated from the Agbaja plateau axis of the basin.

\section{Geological background}

The Bida Basin located at central Nigeria is one of the hinterland sedimentary basins in Nigeria and made up of sedimentary fill of about $3.5 \mathrm{~km}$ (Ojo 1984; Udensi and Osazuwa 2004). It is a northwest-southeast trending intracratonic structural depression adjacent to and contiguous with Sokoto and Anambra Basins in the northwest and southeast, respectively (Fig. 1). The Bida Basin is subdivided into the northern and southern sub-basins probably due to its basin wide facies changes (Jones 1958; Braide 1992). Many published works on the origin of Bida Basin are in support of rift origin for the basin (King 1950; Kennedy 1965; Kogbe et al. 1983; Ojo and Ajakaiye 1989). They put forward robust arguments, supported with geophysical data and land sat imageries, in favour of rift origin associated with drifting apart of South America and Africa plates. Kogbe et al. (1983) observed existence of major faults on both sides of the Niger valley from landsat imageries and confirmed by geophysical investigation. Ojo and Ajakaiye (1989) described the Bida basin as an area of local subsidence and postulated the existence of a deep seated central positive anomaly flanked by negative anomalies which is typical of rift structure. The sedimentary infill in the basin is generally flat lying and there is no evidence of folding or unroofing due to erosion as it is in the lower Benue Trough. The authors agreed that the origin of Bida Basin is associated with the tectonic evolution of the Benue Trough which began in the early Jurassic to early Cretaceous with the opening of Gulf of Guinea. A plate tectonic-based model was later published by Braide (1992) which advanced a wrench fault tectonics for the evolution and thus suggested a pull-apart origin for Bida Basin.

The stratigraphic framework of the upper Cretaceous Bida Basin has been discussed in several published work among which are the work of Adeleye and Dessauvagie (1972) and Adeleye (1989). In order to simplify the stratigraphic framework, they subdivided the basins into two geographic divisions; northern and southern Bida basins, each with distinct mappable stratigraphic units. Agyingi (1993) and Ojo and Akande (2006) presented a detailed description of the stratigraphic succession in the southern Bida Basin. The oldest unit in the southern Bida Basin is the Campanian Lokoja Formation which consists mainly of alluvial to fluvial channel sandstones and minor claystone (Ojo and Akande 2003). It is a stratigraphic equivalent of the Bida Formation in the northern Bida Basin (Fig. 2). This is succeeded by the Maastrichtian Patti Formation, which is the focus of the present investigation. The Patti Formation was deposited in a wide range of environments ranging from shoreface, tidal channels and tidal marsh to coastal swamps. The formation is made up of two members; sandstone and shale-clay members. The sandstone member comprises of the shoreface and tidal facies association (well sorted, fine to medium grained sandstone and minor coarse to very coarse grained sandstone). The shale-clay member comprises of the swamp to marsh facies (shale, lignite, ironstone, siltstone and claystone) (Ojo and Akande 2009). The lateral equivalent of the Patti Formation in the northern Bida Basin is the Enagi Formation. The Agbaja Formation which is the lateral equivalent of the Batati Ironstone in the north capped the entire sequence, and the probable age is late Maastrichtian (Adeleye 1989). Correlation of the stratigraphic successions across the northern and the southern parts of the basin is largely based on the lithological and depositional characteristics and has been extended into the Anambra Basin in the southeast (Fig. 2). These lateral equivalents represent continuous depositional phases from south to north and northwest, and they were controlled by sea level rise and fall during the Upper Cretaceous.

\section{Materials and methods}

Ten samples from the shale-clay member of the Patti Formation, Bida Basin, were selected for analysis. Six of them were selected from Agbaja borehole section (Fig. 3). Figure 4 shows the lithostratigraphic correlation of the newly drilled and investigated borehole section with well-published and documented Agbaja Plateau composite section. It is necessary to mention that, to date, available information shows that the cliff face of Agbaja Plateau offers the most complete section where all the stratigraphic units (Lokoja, Patti and Agbaja Formations) in the southern Bida Basin are represented (Fig. 4). Four samples (three from Ahoko quarry and one from Geheku road cut) (Fig. 5) were also selected. The selection of the samples was based on availability of fresh shale samples from the boreholes and the surface exposures. The locations and the sections are geologically strategic because Agbaja Plateau presents the most complete major stratigraphic successions in the entire Bida Basin (Ojo and Akande 2009) while Ahoko quarry and Geheku road cut present best exposures of the shale-clay member of the Patti Formation. The samples were processed using standard

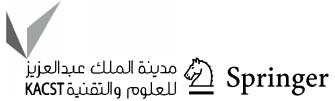




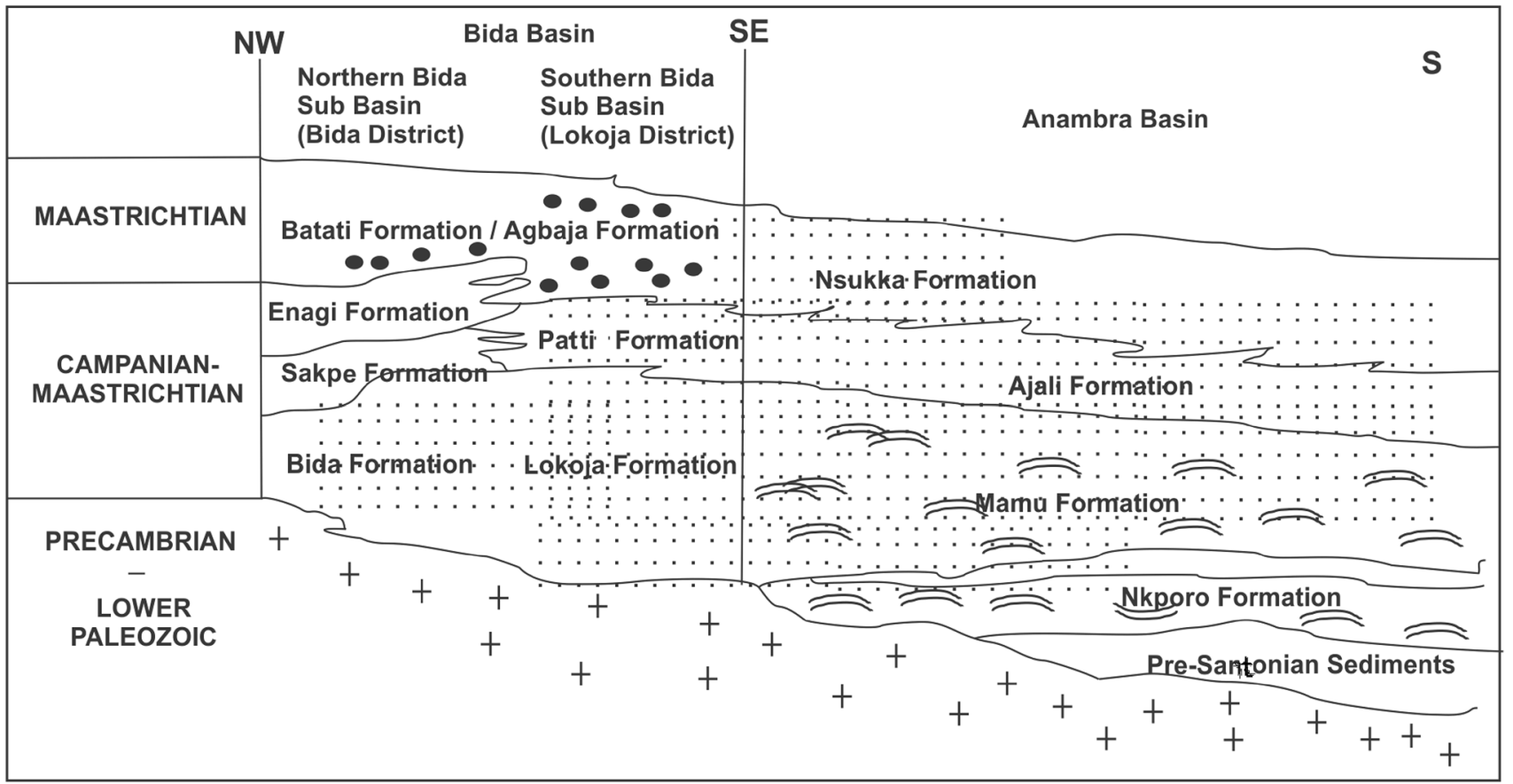

Fig. 2 Stratigraphic framework of the Bida Basin. Note the position of the Patti in the southern Bida Basin

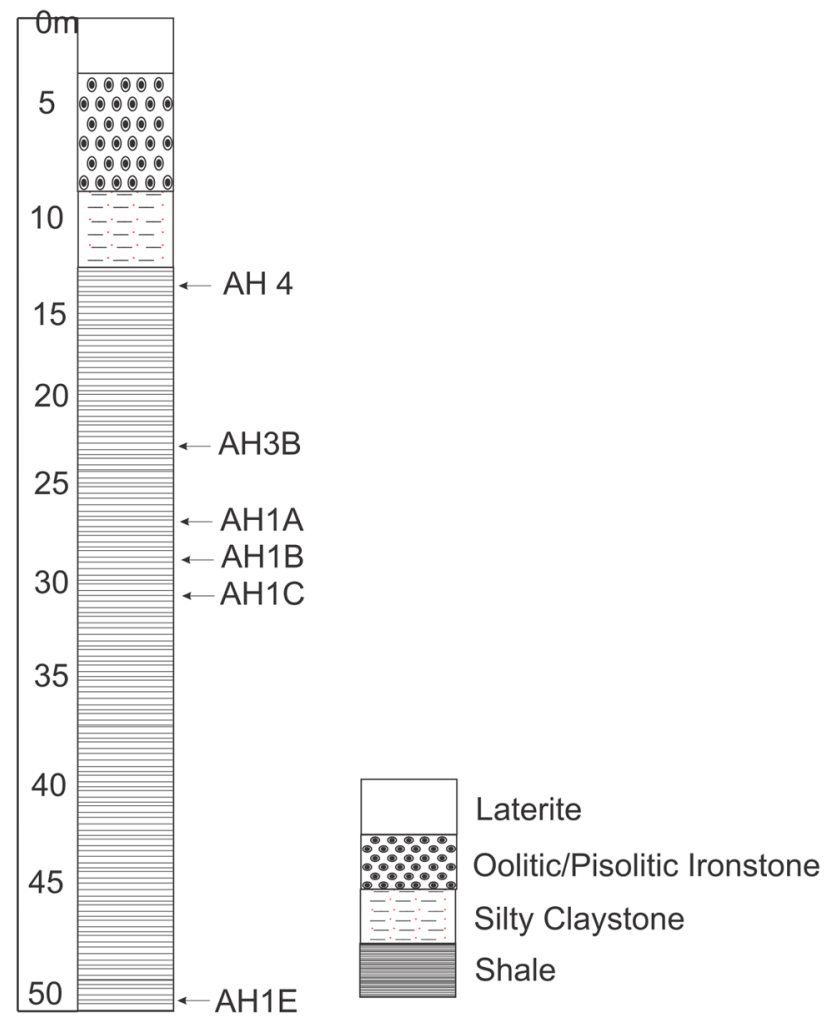

$\mathrm{BH}-1$

Fig. 3 Lithostratigraphic profile of borehole 1 at Agbaja. Note the sampled intervals palynological processing and also subjected to organic geochemical screening (TOC and Rock-Eval pyrolysis) to obtain information on the quantity, quality, source and thermal maturity of the organic matters. Organic petrology (visual kerogen and maceral analysis) was also carried out using a Leitz MPV-2 photomicroscope to complement the Rock-Eval pyrolysis data. Kerogens were extracted from the three shale samples using acid treatment. $10 \% \mathrm{HCl}$ was used for the removal the carbonates, and the residue was later treated with $15 \%$ HF. The solution was decanted after centrifuging, neutralized and the residue dried. These processes were followed by microscopic analysis of the macerals using reflected microscope equipped with white incident light and blue light irradiation. The reflectance of the vitrinite particles was measured for each sample according to Stach et al. (1982) and Bustin et al. (1983). Gas chromatography, medium performance liquid chromatography and gas chromatography-mass spectroscopy were used to analyse some of the source rock extracts for biomarker fingerprints.

\section{Results and discussion}

\section{Palynological and palynofacies characteristics}

Samples from Agbaja borehole, Ahoko quarry and Geheku road cut, southern Bida basin yielded well-preserved palynomorphs that are useful for biostratigraphic, paleoclimatic and paleoecologic deductions. The pollen and spores were 
Fig. 4 Lithostratigraphic correlations of exploratory boreholes with the composite section of Lokoja, Patti and Agbaja Formations at Agbaja

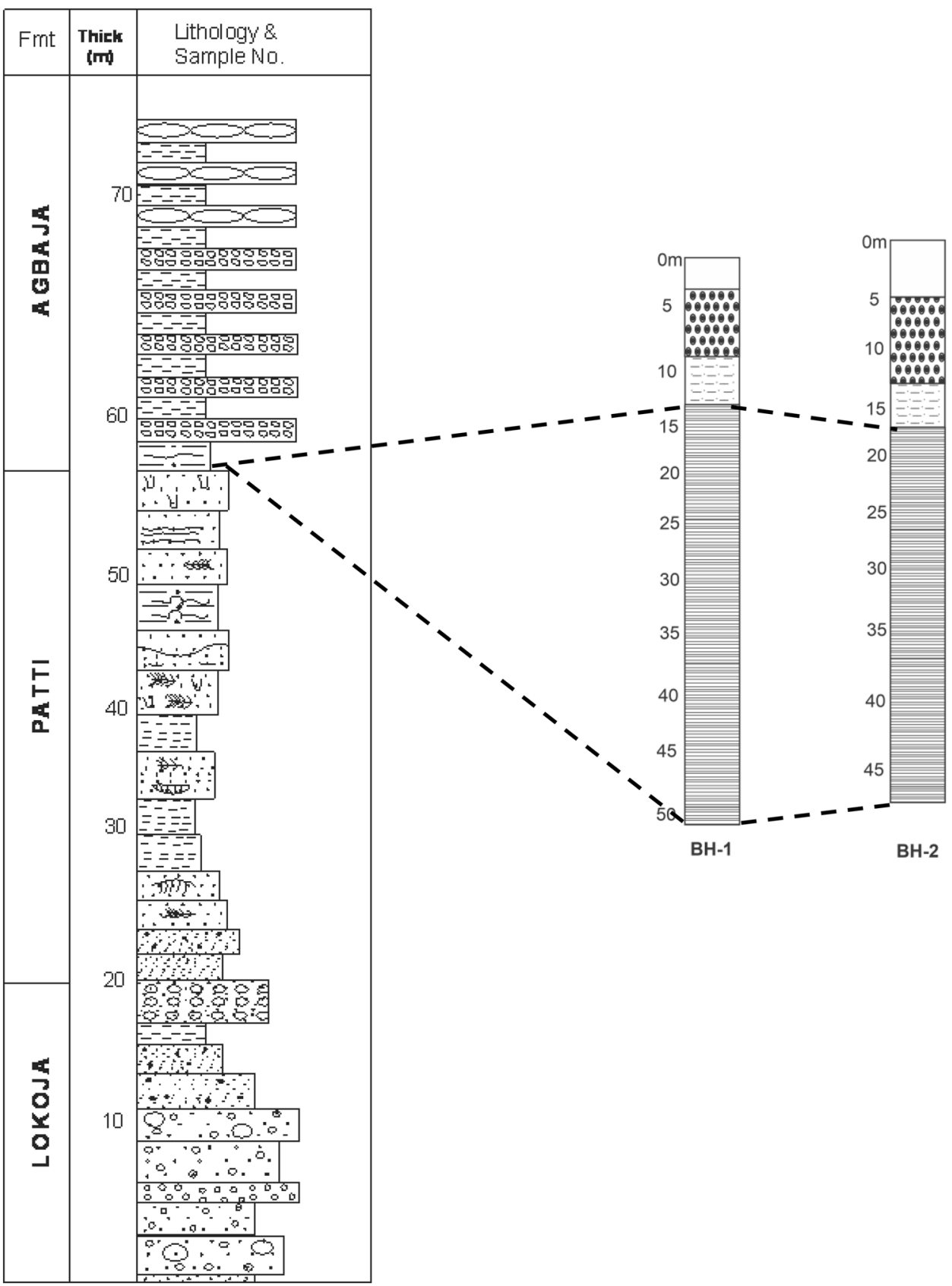

identified using palynological catalogues of Lawal and Moullade (1986), Germeraad et al. (1968), Salard-Cheboldaeff $(1981,1990)$, Van Hoeken-Klinkenberg $(1964,1966)$ and Jan du Chene et al. (1978), while for the dinoflagellates, species nomenclature scheme of Fensome and Williams (2004) and the catalogue of Powell (1992) and Jan Du Chene (1987) were followed. The palynomorphs from the study areas include Retidiporites magdalenensis Van Der Hammen and Garcia de Mutis 1965, Echitriporites trianguliformis Van Hoeken Klinkenberg 1964, Buttinia andreevi Boltenhagen 1978 and Foveolotriletes magaritae Germeraad et al. 1968. Others include Distaverrusporites complex Muller 1968,
Cingulatisporites ornatus Van Hoeken Klinkenberg 1964 and Proteacidites sigalii Boltenhagen 1978 (Figs. 6, 7, 8). These are known Maastrichtian forms (Salami 1983, 1990), and therefore, the shales are assigned Maastrichtian age. In fact a presumably younger form; Proxapertites cursus Van Hoeken Klinkenberg 1966 and from some of the intervals is suggestive that the sediments may even range into Paleocene? Agyingi (1993) and Ojo and Akande (2006, 2008) have reported Campanian - Maastrichtian and Maastrichtian age for the shales from Ahoko road exposures, respectively. It therefore means that the shales at Agbaja and Ahoko quarry are lateral equivalents and of Maastrichtian age. The 

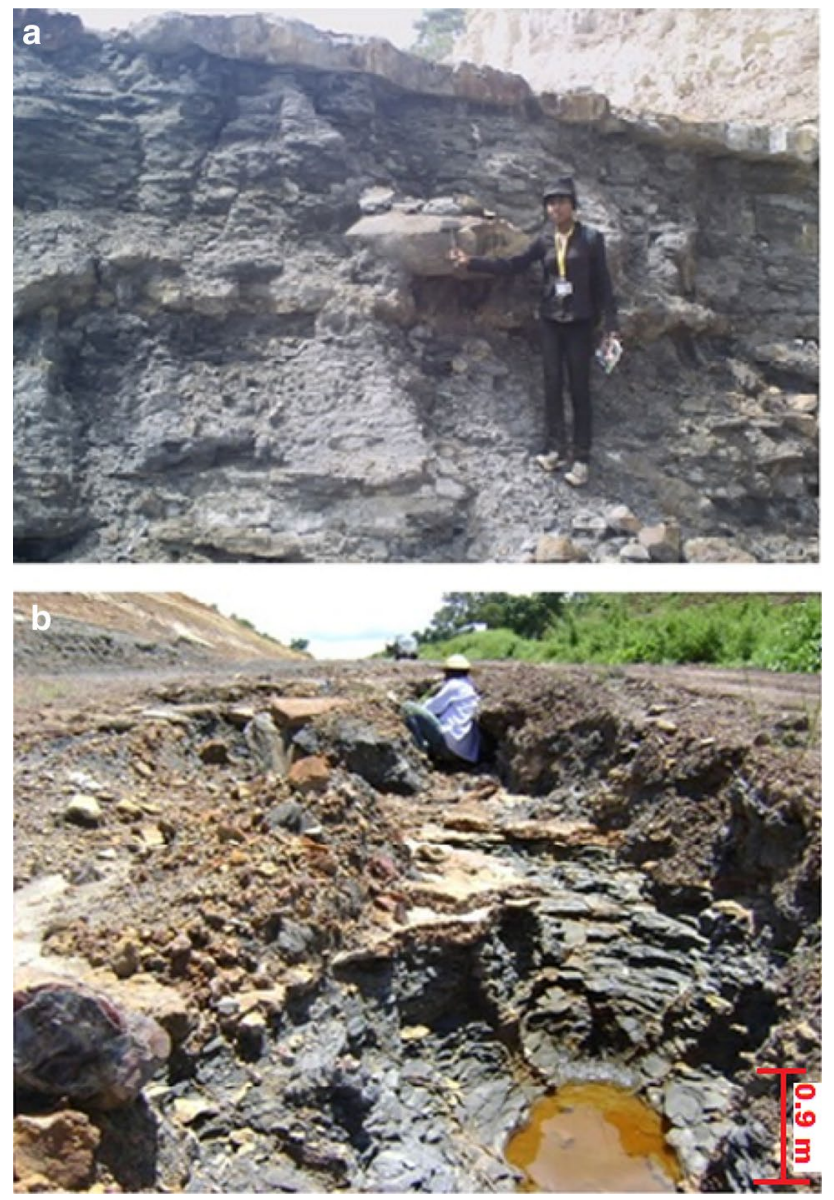

Fig. 5 Field photographs of the investigated shales at a Ahoko quarry (note height of the lady $1.55 \mathrm{~m}$ ) and $\mathbf{b}$ Geheku road cut

borehole logs reported in this present study reveal that shale lithology occurred on top of the sandstone and at the base of the oolitic ironstone. The lithostratigraphic correlation is presented in Fig. 4. This study has confirmed the occurrence of shale at Agbaja, its stratigraphic position and dated it Maastrichtian. It is established as a lateral equivalent of the shale at Ahoko, and therefore, the shale is older and it is at the base of Agbaja Ironstone. Further evidence on the Maastrichtian age of the shales is provided by marine dinocysts such as Senegalinium bicavatum Jain and Millepied 1973, Dinogymnium acuminatum Evitt 1969, microforaminifera linings and Spiniferites ramosus Lentin and Williams 1973 which are well known in Maastrichtian sediments in Egypt and Senegal (Jain and Millepied 1973; Schrank 1984; Sultan 1985) and in Nigeria (Oloto 1987).

The occurrence of Botryococcus braunii Erdtman 1952 in the Patti shale at Agbaja borehole section was recorded. This is a typical freshwater alga indicative of freshwater swamp and presumably lacustrine source rock. At Ahoko and Geheku sections, marine dinocysts were recovered from the basal part of the section and this interval is considered to mark the maximum flooding surface in the basin. The relative abundance of Senegalinium bicavatum Jain and Millepied 1973, Dinogymnium acuminatum Evitt et al. 1977 and species of the spiniferate group (Spiniferites ramosus Lentin and Williams 1973) at this interval is an indication of marine water at this level. Interestingly, it is in this part of the section where high diversity of the dinocysts and highest population were observed. Schrank (1984) and Helenes et al. (1998) opined that high abundance of marine dinocysts compared to the terrestrially derived pollen and spore is an evidence of marine condition. The spore and pollen assemblage recovered from both sections (Agbaja borehole and Ahoko quarry) permit constraining of the paleoclimatic scenario during the Maastrichtian which has implications for the source rock characteristics. The data show presence of microfloral that are associated with Late Cretaceous Palmae Province (Schrank 1984). Among these include Foveomonocolpites bauchiensis van Hoeken-Klinkenberg 1964, Echitricolpites longispinosus Schrank 1994, Retiporites magdalensis Van Der Hammen and Garcia de Mutis 1965, Monocolpites marginatus Van der Hammen 1954 and Longapertites marginatus van Hoeken-Klinkenberg 1964. These pollen grains and the presence of Petridophyte elements dominated by the trilete spores (Cyatheacidites minor Couper 1953 and Gleicheniidites senonicus Ross 1949) (Figs. 6, 7, 8) are indicative of wet mangrove to marsh vegetation within predominantly warm and humid climate. This observation is not exclusive to this basin but rather correlates with similar condition reported for the Maastrichtian shales and coals in Gongola Basin (northeast Nigeria), Anambra basin (southeast Nigeria) (Jan du Chene et al. 1979; Salami 1990; Ojo and Akande 2004). It can be inferred therefore that under this condition, high organic productivity probably subsisted and favoured high organic matter accumulation in the source beds.

Ever since organic petrologists and geochemists become more aware of the potential of dispersed organic matter in the assessment of quality, source of organic matter and hydrocarbon potential of source rocks, many researchers have proposed palynofacies classifications schemes (Tissot et al. 1974; Masron and Pocock 1981; Batten 1983, 1996). Types of organic matter are considered very important in the assessment of source rock potential, and they must be distinguished as different types of organic matter have different hydrocarbon potentials and products (Thakur and Dogra 2011). In this study, the scheme of Tyson (1995) is adopted. Three classes adopted include amorphous organic matter (AOM), phytoclasts and palynomorphs (Table 1). The amorphous organic matter AOM includes all particulate organic components that appear structureless at the scale of light microscopy, including bacterially derived AOM, resinous and amorphous products of the diagenesis of macrophyte tissues. Palynomorphs are essentially spores, pollen, dinocysts, 


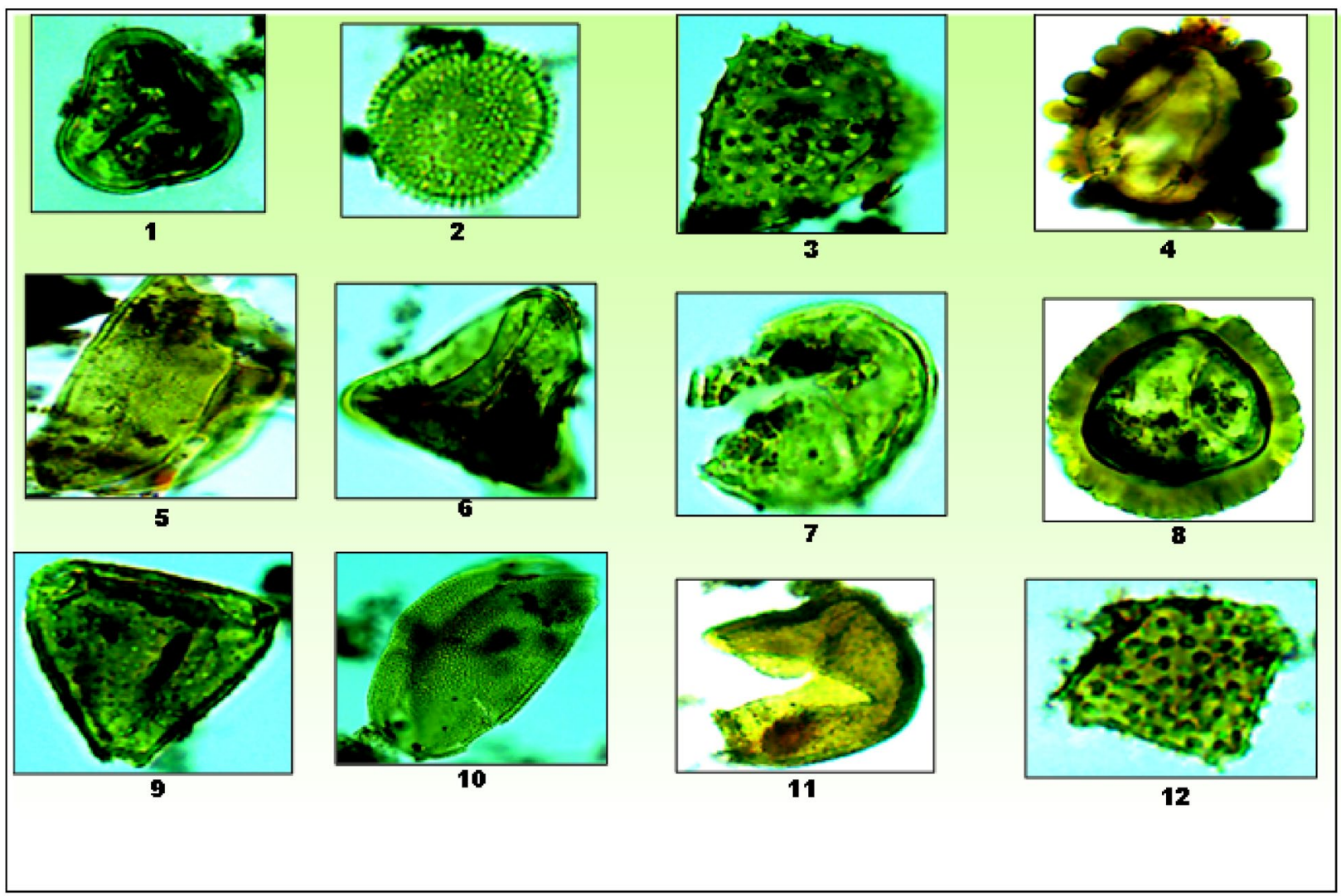

Note: 1. Cyathidites sp. X400 Couper 1953; 2.Constructipollenites ineffectus X400 Van Hoeken-Klinkenberg 1964; 3. ?Proteacidites longispinosus X1000 Jardiné and Magloire 1965; 4. Distaverrusporites simplex X1000 Muller 1966; 5. Longapertites marginatus X1000 Van Hoeken-Klinkenberg 1964; 6. Gleicheniidites senonicus X1000 Ross 1949; 7. ?Monocolpopollenites sphaeroidites X1000 Jardiné and Magloire 1965; 8.Cingulatisporites ornatus X1000 Van Hoeken-Klinkenberg 1964; 9. ?Proteacidites sigalii X1000 Boltenhagen 1978; 10. Longapertites microfoveolatus X1000 Jan Du Chene et al. 1978; 11. Foveolatus margaritae X400 Germeraad et al. 1968; 12. Echitriporites trianguliformis X400 Van Hoeken-Klinkenberg 1964.

Fig. 6 Some Maastrichtian marker palynomorphs from the source rock intervals at Agbaja Borehole and Ahoko quarry

microforaminiferal lining, fungi and algae, while Phytoclasts include structured terrestrial plant fragments such as cuticles, wood tracheid and cortex tissue, black debris (oxidized or carbonized brownish black to black coloured woody tissues including charcoal) (Tyson 1995). Palynofacies analysis of the investigated samples suggests predominance of structured organic matter in the source rock intervals and minor amorphous organic matter suggesting predominance of gas prone type III organic matter (Table 1). The amorphous organic matter in the shales from Agbaja borehole amounts to about $16 \%$ indicating probably type II-III organic matter (oil and gas prone). The APP plot according to Tyson (1995) suggests dysoxic to oxic conditions and transition from shelf to basin for the source rock intervals (Fig. 9).

\section{Organic richness and Kerogen quality}

The total organic carbon (TOC) of the samples in the study area exceeds $0.5 \mathrm{wt} \%$ (Table 2), indicating that they meet requirement for hydrocarbon source rocks (Peters and Cassa 1994; Adegoke et al. 2014). A significant variation in the organic matter concentration (as measured by TOC) of the shales along the sample locations is observed, with the samples from Agbaja Borehole presenting higher values (0.77 to 


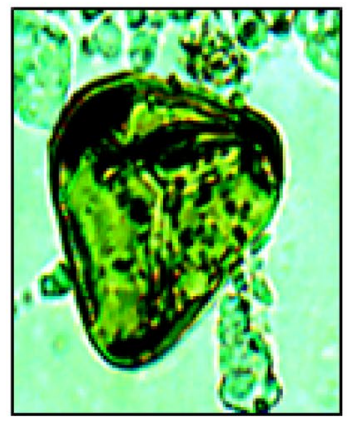

1

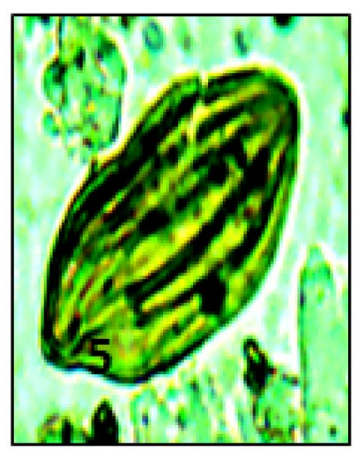

5

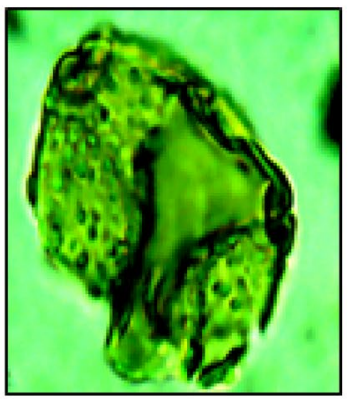

9

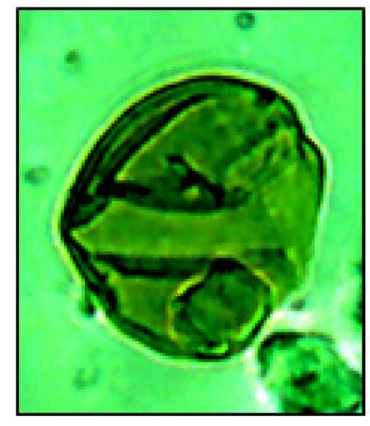

2

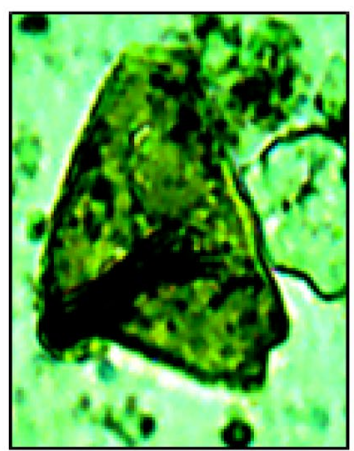

6

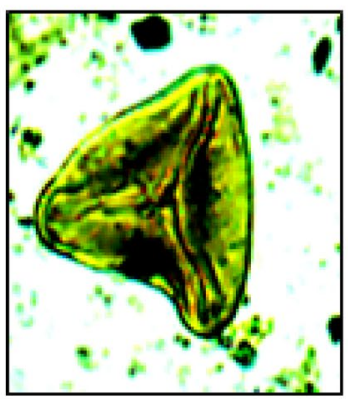

10

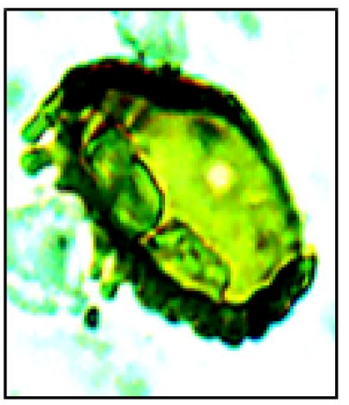

3

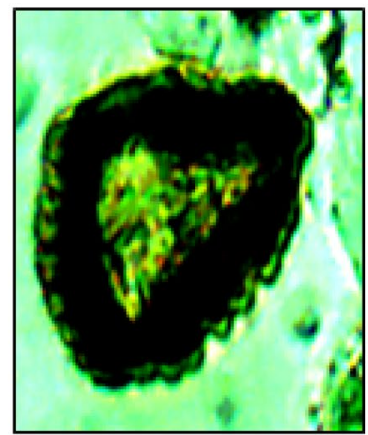

7

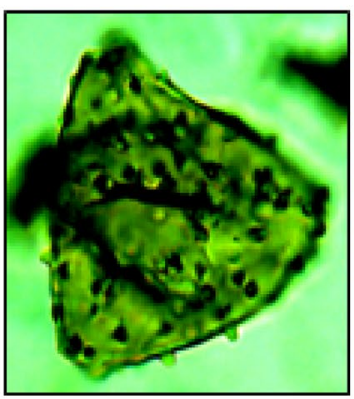

11

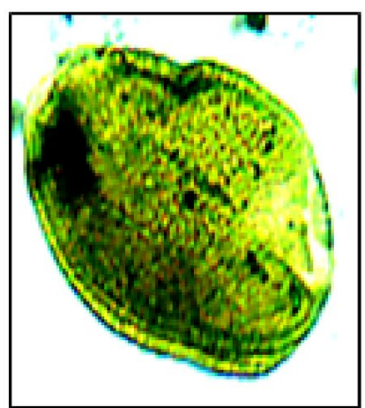

4

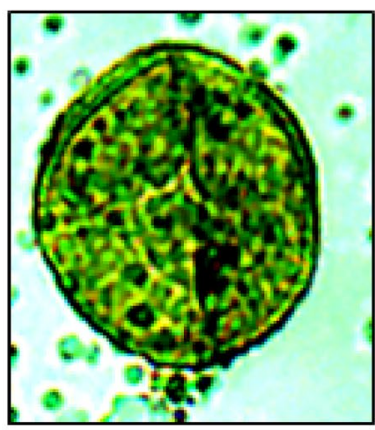

8

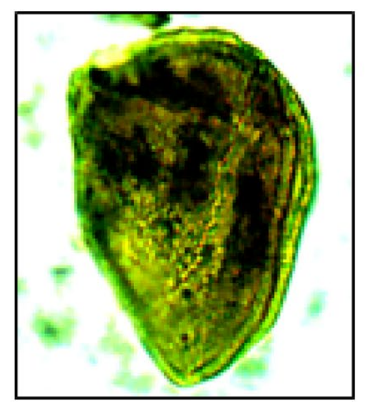

12

Note: 1. Cyatheacidites minor X400 Couper 1953; 2.Monocolpites marginatus X400 Van der Hammen 1954; 3. Tubistephanocolporites cylindricus X400 Schrank 1994; 4. Proxapertites cursus X400 Van Hoeken Klinkenberg 1966; 5. Ephedripites sp. X400 Jardiné and Magloire 1965; 6. Proteacidites sigalii X400 Boltenhagen 1978; 7. Distaverrusporites simplex X400 Muller 1968; 8. Rugulatisporites caperatus X400 Van Hoeken-Klinkenberg 1964; 9. ?Scabratriporites annellus X1000 Van Hoeken-Klinkenberg 1964; 10. Gleicheniidites senonicus X400 Ross 1949; 11. Echitriporites trianguliformis X1000 Van Hoeken Klinkenberg 1964; 12. Longapertites marginatus X400 Van Hoeken-Klinkenberg 1964.

Fig. 7 Some Maastrichtian marker palynomorphs from the source rock intervals at Agbaja Borehole and Ahoko quarry

$8.95 \mathrm{wt} \%$ average $4.76 \mathrm{wt} \%)$ than those from Ahoko quarry ( 0.79 to $2.29 \mathrm{wt} \%$, average of $1.29 \mathrm{wt} \%$ ) and Geheku road cut $(1.74 \mathrm{wt} \%)$. The results show that the source rocks from the Agbaja borehole are richer in organic matter concentration and therefore good source rocks, while source rocks from Ahoko and Geheku are lean in organic matter. The 


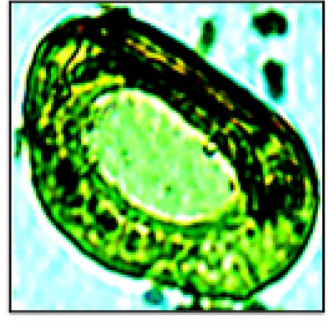

1

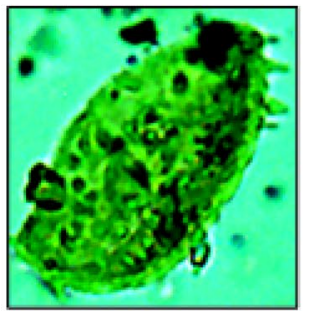

5

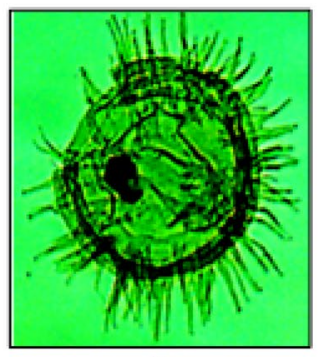

9
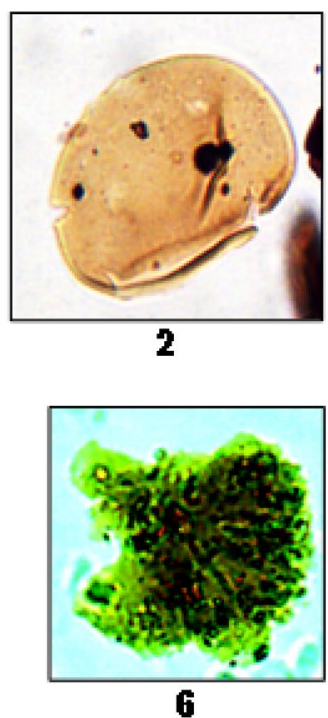

6

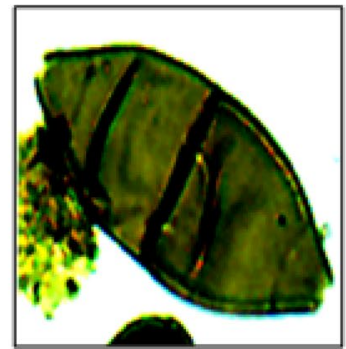

10

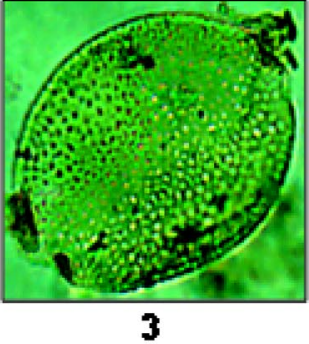

3
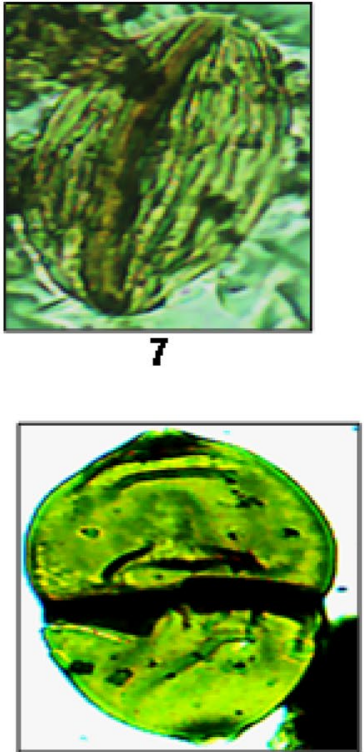

11

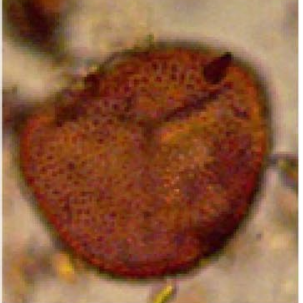

4
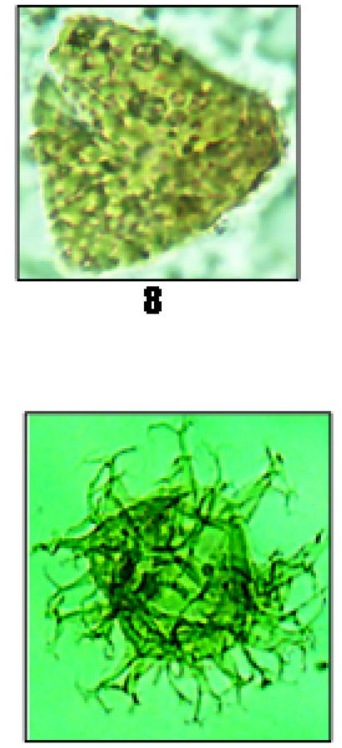

12

NB: 1. Milfordia sp. X400 Agyingi 1993; 2.Laerigatosprorites sp. X400 Raine et al. 2011; 3. Proxapertites curcus sp. X400 Van Hoeken-Klinkenberg 1966; 4. Fiveotriletes margarites X400 Germeraad et al. 1968; 5.Spnizonocolpites echinatus X400 Muller 1968;

6. Botryococcus braunii X400 Erdtman 1952; 7. Striamonocolpites recto striatus X400 Salard-Cheboldaeff 1990; 8. Echitriporites trianguliformis X400 Van Hoeken-Klinkenberg 1964; 9. Spiniferites ramosus X400 Lentin and Williams 1973; 10. Fungal spore X400 Erdtman 1952; 11. Dinogymnium sp. X400 Evitt et al. 1977; 12. Spiniferites sp. X400 Evitt 1969.

Fig. 8 Some Maastrichtian marker palynomorphs from the source rock intervals at Agbaja Borehole and Ahoko quarry

variation may be due to preservation conditions as samples from Ahoko quarry and Geheku road sections were more exposed to subaerial weathering conditions. The quality of the organic matter contained in the samples was evaluated from their Hydrogen Index (HI). HI ranged between $13 \mathrm{mgHC} / \mathrm{gTOC}$ and $114 \mathrm{mgHC} / \mathrm{gTOC}$ in most of the samples indicating poor quality (Table 2). However, a shale sample (AH 4) from Agbaja borehole has HI of $274 \mathrm{mgHC} /$ gTOC indicating type II-III and type II kerogens which are capable of generating oil and gas (Figs. 10, 11, 12) (Hunt 1996). Similar trend is recorded for the Rock-Eval S2 which ranges from 0.1 to $24.5 \mathrm{mgHC} / \mathrm{g}$ rock and 0.05 to $0.66 \mathrm{mg}$
HC/gTOC in Agbaja and Ahoko samples, respectively. In spite of the relatively high TOC of the samples, particularly those from Agbaja borehole, the HI is generally low and this we thought may be attributed to high organic productivity but poor preservation condition and scarcity of lipid rich marine zooplanktons (Bohacs et al. 2000). Pervasive oxidation and extensive grazing under oxic condition would lead to the consequence of hydrogen depletion in the organic materials and therefore low HI (El Diasty et al. 2016a, b; El Atfy et al. 2017). This line of thought is in harmony with the paleoclimatic deductions (abundance of mangrove vegetation and short-lived marine incursion during Maastrichtian) 
Table 1 Quantitative distribution of palynofacies particles recorded from the investigated shales of the Patti Formation

\begin{tabular}{lllll}
\hline S/N & Sample no. & $\begin{array}{l}\text { Phytoclasts } \\
(\%)\end{array}$ & AOM (\%) & $\begin{array}{l}\text { Palyno- } \\
\text { morphs } \\
(\%)\end{array}$ \\
\hline 1 & AH1A & 54 & 24 & 22 \\
2 & AH1B & 47 & 38 & 15 \\
3 & AH1C & 56 & 27 & 17 \\
4 & AH1E & 59 & 35 & 6 \\
5 & AH3B & 25 & 60 & 15 \\
6 & AH4 & 16 & 72 & 12 \\
7 & BH15 & 44 & 38 & 18 \\
8 & JAH1A & 49 & 30 & 21 \\
9 & JAH1Q & 43 & 40 & 17 \\
10 & JAH1U & 57 & 18 & 25 \\
\hline
\end{tabular}

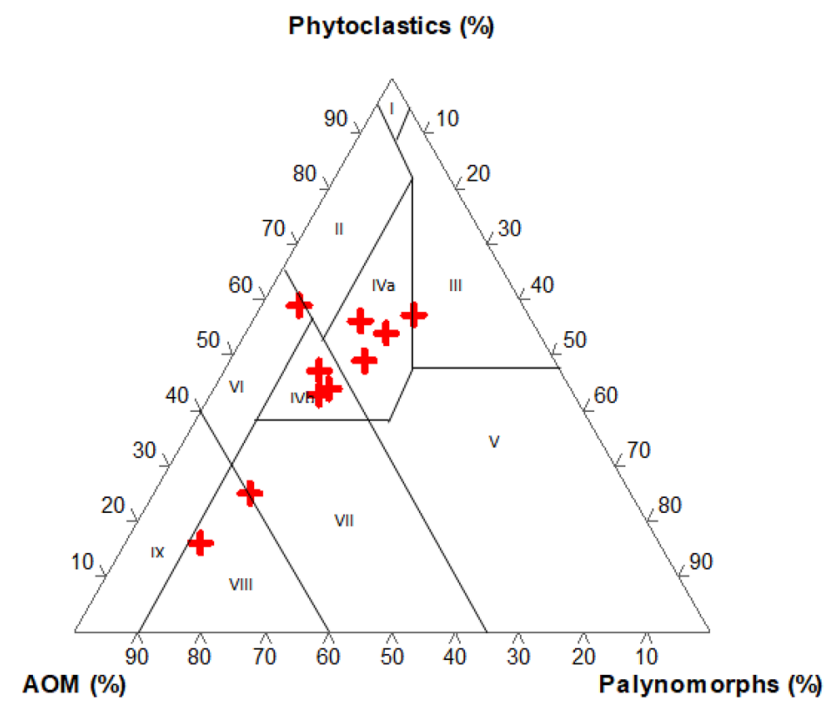

Fig. 9 Ternary diagram of the APP Palynofacies for the investigated samples from Agbaja borehole and Ahoko quarry. I Highly proximal shelf or basin, II Marginal dysoxic-anoxic basin, III Heterolithic oxic shelf ('proximal shelf'), IV Shelf to basin transition, V Mud-dominated oxic shelf ('distal shelf'), VI Proximal suboxic-anoxic shelf, VII Distal dysoxic-anoxic 'shelf', VIII Distal dysoxic-oxic shelf, IX Distal suboxic-anoxic basin

indicated above. The organic matter in the studied samples is largely type III indicating contributions from terrestrial higher plants and gaseous hydrocarbon potential (Langford and Blanc-Valleron 1990). However, sample AH4 from Agbaja borehole, with elevated HI and Rock-Eval S2 values, is presumably indicative of probably a localized and short-lived anoxic condition and organic matter contributions from lipid zooplanktons and terrestrial plants. Therefore, availability of liquid hydrocarbon generating kerogens in this part of the Bida Basin cannot be ruled out (Peters and Cassa 1994). The Rock-Eval $T_{\max }$ for the shales ranges from 413 to $435{ }^{\circ} \mathrm{C}$ with exception of sample AH1E from Agbaja with $T_{\max }$ of $475^{\circ} \mathrm{C}$. This anomaly may due to highly oxidized nature of the organic materials rather actual thermal maturity. Highly burnt and inert organic matter do show anomalous high $T_{\max }$ (Powell et al. 1991). It is important to note that the same sample show extremely high Oxygen Index (OI) of $220 \mathrm{mgCo}_{2} / \mathrm{g}$ TOC. Vitrinite reflectance ranges from 0.46 to 0.48 Ro\% (Tables 2 and 3). This is an indication that most of the samples are immature and barely within the oil window (Espitalie et al. 1985; Akande et al. 2005). In addition, we plotted Rock-Eval S1 against TOC and the plot shows no sign of non-indigenous or migrated hydrocarbon (Fig. 13). Apart from the Rock-Eval $T_{\max }$ and maceral indicators, the molecular geochemical marker was also applied in this study. The carbon preference index (CPI) is greater than unity, and in conjunction with other saturate and aromatic maturity indices (Table 4) lend credence to the immaturity status of the samples. Saturated and aromatic hydrocarbon biomarker can be used to deduce the thermal maturity of the rock. Disteranes are more stable and survive thermal degradation than sterane. At high level of thermal maturity, disterane/sterane ratio is high (Seifert and Moldowan 1980). The disterane/sterane ratio detected by m/z 217 for the Agbaja and Ahoko samples are 0.09 and 0.63 , respectively, which is generally low. The ratio of moretanes/hopanes for mature oils ranges from 0.05 to 0.15 (Mackenzie et al. 1980; Seifert and Moldowan 1980). The value for the ratio of moretane/hopane in sample AH4 (Agbaja) is 0.44, while that of JAH1Q (Ahoko) is 0.61 which also indicate that the samples are immature. This is supported by the production index PI $(<0.1)$ which therefore shows that even though the organic matter concentration is relatively high, the thermal conversion condition is low for hydrocarbon generation and expulsion in the basin. The low maturity of the shales may not be unconnected with the fact the samples studied are from shallow wells, quarry and road sections. Apart from these, published literature shows that most Campanian to Maastrichtian shales from inland basins in Nigeria; for example, the Enugu and Mamu Formations (Anambra Basin) and Gombe Formation (Gongola Basin) (Obaje et al. 2004; Ojo et al. 2009; Jimoh and Ojo 2016) are immature to barely mature. In Bida Basin, apart from the stratigraphic age, our field experience and available literature reveal that factors such as lack of enough sedimentary cover, substantial subsidence, post/syn-tectonic-magmatic activities and tectonic reactivation or mobilization could have jointly played a role in preventing sufficient thermal transformation. Therefore, in our considered opinion, at deeper level, the source rocks may just be at the onset of oil window. This is an important point in developing exploration strategy for the basin. 
Table 2 Results of TOC and Rock-Eval pyrolysis data from the analyzed shales of the Patti Formation. TOC: Total Organic Carbon, wt $\% ; \mathrm{S}_{1}$ : Free hydrocarbon content, mg HC/grock; $\mathrm{S}_{2}$ : Remaining hydrocarbon generative potential, $\mathrm{mg} \mathrm{HC/g}$ rock; $\mathrm{S}_{3}$ : Carbon diox- ide yield, mg $\mathrm{CO}_{2} / \mathrm{g}$ rock; $\mathrm{HI}$ : Hydrogen Index $=\mathrm{S}_{2} \times 100 / \mathrm{TOC}, \mathrm{mg}$ HC/g TOC; OI: Oxygen Index $=\mathrm{S}_{3} \times 100 / \mathrm{TOC}, \mathrm{mg} \mathrm{CO} / \mathrm{g}$ TOC; $T_{\max }$ : Temperature at maximum of $\mathrm{S}_{2}$ peak; PI: Production index $=$ $\mathrm{S}_{1} /\left(\mathrm{S}_{1}+\mathrm{S}_{2}\right)$

\begin{tabular}{|c|c|c|c|c|c|c|c|c|c|c|c|c|}
\hline $\mathrm{S} / \mathrm{N}$ & Sample code & Location & TOC (wt/\%) & $\mathrm{S}_{1}$ & $\mathrm{~S}_{2}$ & $\mathrm{~S}_{3}$ & $\mathrm{~S}_{1}+\mathrm{S}_{2}$ & $T_{\max }\left({ }^{\circ} \mathrm{C}\right)$ & $\mathrm{HI}$ & OI & $\mathrm{S}_{1} / \mathrm{TOC}$ & PI \\
\hline 1 & JAH1A & Ahoko Quarry & 0.79 & 0.02 & 0.17 & 0.33 & 0.19 & 413 & 22 & 42 & 3 & 0.11 \\
\hline 2 & JAH1U & & 0.82 & 0.02 & 0.05 & 0.63 & 0.07 & 431 & 61 & 77 & 2 & 0.04 \\
\hline 3 & JAH1Q & & 2.26 & 0.03 & 0.70 & 1.17 & 0.73 & 419 & 31 & 52 & 1 & 0.04 \\
\hline 4 & BGH1A & Geheku road section & 1.74 & 0.04 & 0.66 & 1.32 & 0.70 & 423 & 38 & 76 & 2 & 0.06 \\
\hline 5 & AH1A & Agbaja corehole & 6.16 & 0.13 & 3.31 & 3.45 & 3.44 & 423 & 54 & 56 & 2 & 0.04 \\
\hline 6 & AH1B & & 6.26 & 0.07 & 2.59 & 1.36 & 2.66 & 429 & 114 & 60 & 3 & 0.03 \\
\hline 7 & AH1C & & 3.80 & 0.12 & 3.12 & 1.98 & 3.24 & 422 & 82 & 52 & 3 & 0.04 \\
\hline 8 & AH1E & & 0.77 & 0.02 & 0.10 & 1.69 & 0.12 & 475 & 13 & 220 & 3 & 0.17 \\
\hline 9 & AH3B & & 2.63 & 0.10 & 2.49 & 1.44 & 2.59 & 425 & 95 & 55 & 4 & 0.04 \\
\hline 10 & $\mathrm{AH} 4$ & & 8.95 & 0.68 & 24.50 & 3.99 & 25.18 & 424 & 275 & 45 & 8 & 0.03 \\
\hline
\end{tabular}

\section{Source of organic matter and depositional environment}

Generally, the palynological characteristics of the studied sections indicate freshwater to brackish water conditions. In most of the samples, the palynomorph assemblage is exclusively terrestrial, and occurrence of Botryococcus braunii Erdtman 1952 in the Patti shale at Agbaja borehole section was recorded. This is a typical freshwater alga indicative of freshwater swamp. However at Ahoko and Geheku sections, marine dinocysts (Senegalinium bicavatum Jain and Millepied 1973, Dinogymnium acuminatum Evitt et al. 1977 and Spiniferites ramosus Lentin and Williams 1973) were

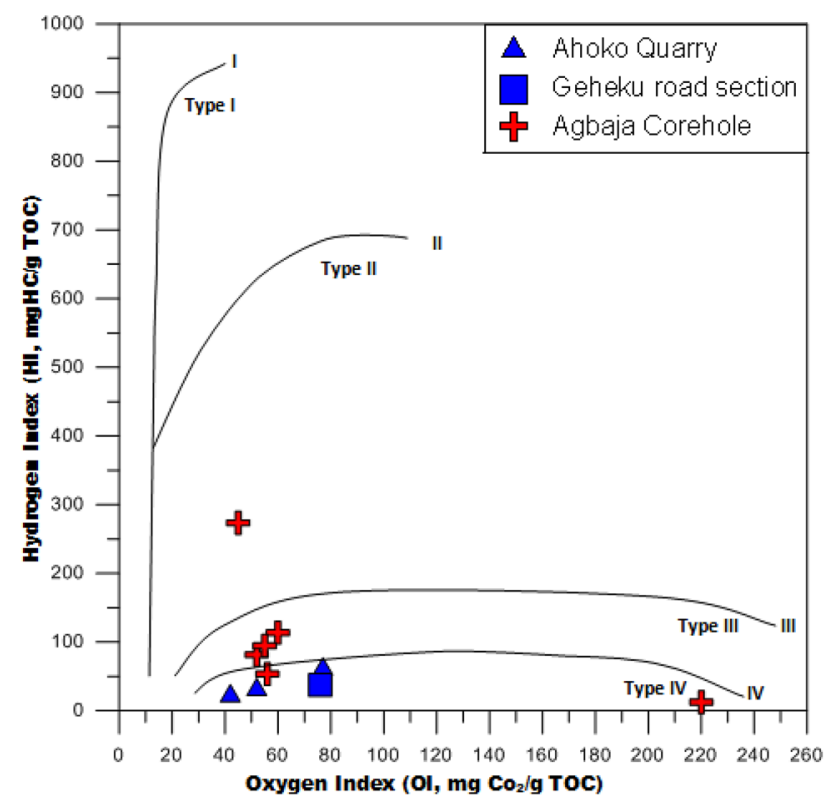

Fig. 10 Plot of HI versus OI for the samples from the study area recovered at the lower part of the section and this interval is interpreted to mark the maximum flooding surface in the basin.

Palynofacies analysis of the investigated samples suggests predominance of structured organic matter in the source rock intervals and minor amorphous organic matter, suggesting that the organic matters were terrestrially sourced. This is supported by various plots of HI versus OI and HI versus $T_{\max }$ (Figs. 10 and 11, respectively) which show preponderance of terrestrially derived type III organic matter. The visual kerogen analysis also reveals the maceral composition as dominated by vitrinite ( 25 to $80 \%$ with average of $55 \%$, Table 3 ) which are essentially derived from terrestrial higher plants.

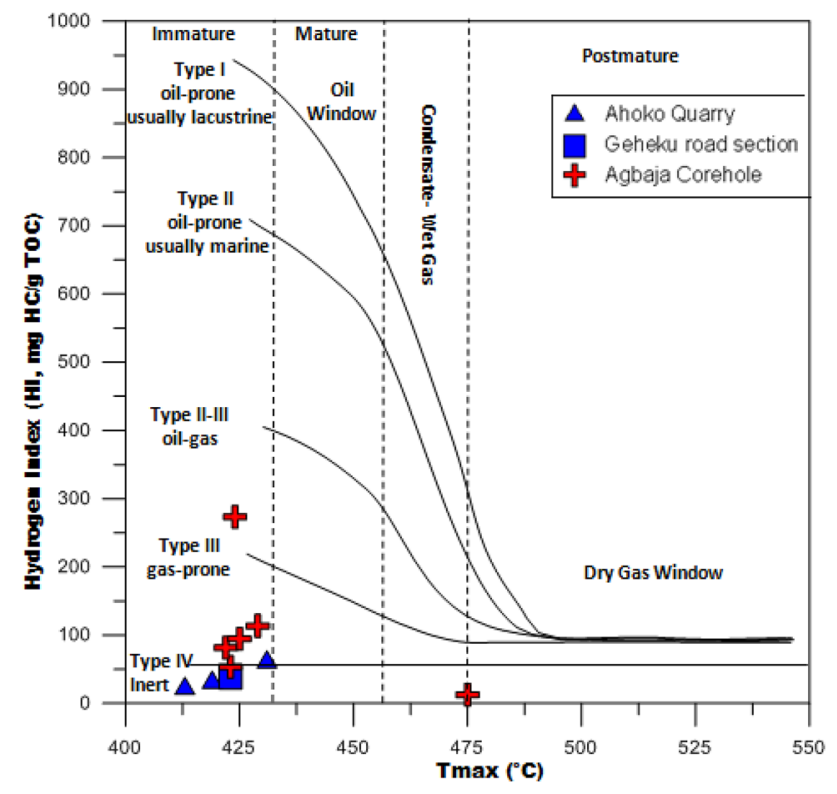

Fig. 11 Plot of HI versus $T_{\max }$ for shale samples from Patti Formation, Bida Basin 


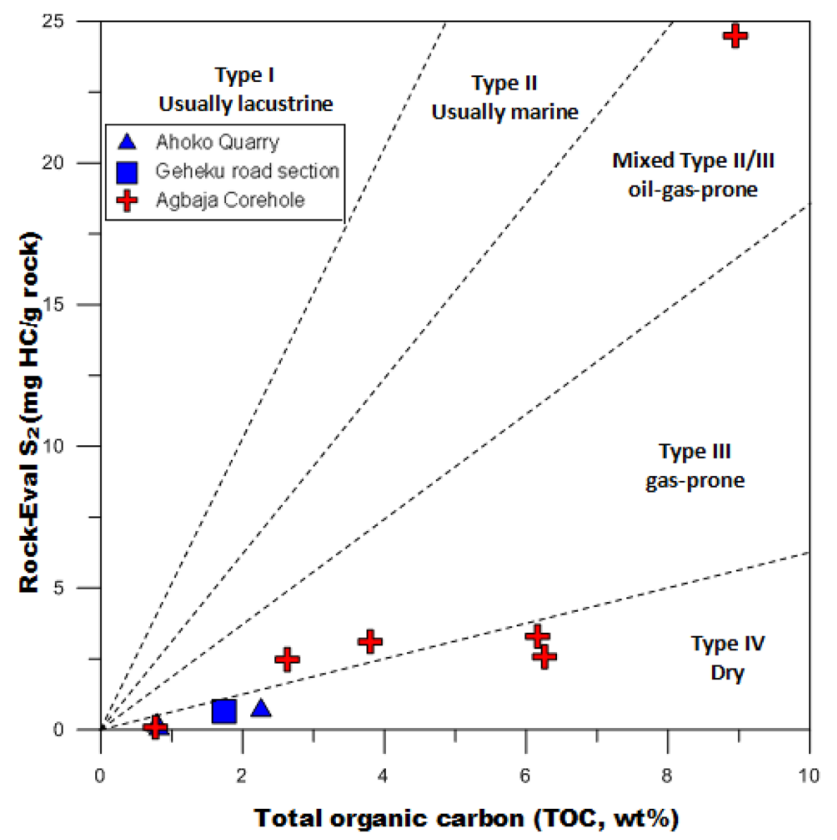

Fig. 12 Plot of S2 versus TOC for shale samples from Patti Formation, Bida Basin

According to Peters and Moldowan (1993), the relative abundance of odd versus even numbered alkanes often expressed as carbon preference index (CPI) provides an indication of the origin of organic matters. Relatively high CPI values in excess of 3 were obtained from the studied shales (Table 4) and therefore indicate that the organic matters were sourced from higher plants. The shales are characterized by high molecular weight $n$-alkanes which range from $\mathrm{C}_{9}$ to $\mathrm{C}_{41}$. The relatively high abundance of heavier $n$-alkanes is typical of mainly land plants (Samuel et al. 2009). The $n$-alkanes distributions in the source rocks maximizes at $\mathrm{C}_{29}$ (Fig. 14), and this pattern indicates organic matter derived mainly from terrestrial organic matter (Ehinola et al. 2005). Average $\mathrm{Pr} / \mathrm{Ph}$ ratio for the analysed samples is 2.66 which suggest non-marine swamp depositional environment in suboxic to oxic setting (Peters et al. 2005). The predominance of Pristane $\left(n-\mathrm{C}_{17}\right)$ over Phytane $\left(n-\mathrm{C}_{18}\right)$ suggests terrestrial higher plants as the main precursor for the organic matters. This is in support of significant land plant contribution as evidenced from the very low $\mathrm{C}_{27}$ steranes (Adegoke et al.
2015). The sterane/hopane ratio values range from are less than 0.6 suggesting incorporation of high level of bacterial inputs commonly associated with terrigenous organic matter.

\section{Conclusions}

We obtained new palynological and geochemical data from the shales recovered from an exploration borehole at Agbaja and a Ahoko quarry. The shales from Agbaja and Ahoko sections are dated Maastrichtian and are stratigraphic equivalents. They are older than Agbaja Ironstone and were deposited in a largely non-marine swamp environment inundated by a short-lived sea transgression. Palynological evidence suggests humid warm tropical climate which supported high productivity of palmae type pollen and pteridophytic plants.

Patti Formation shales constitute fair to moderate source rocks with potential to generate mainly gas. Type II-III kerogen capable of generating gas and oil is, however, documented in the Patti shale from Agbaja and may probably generate oil

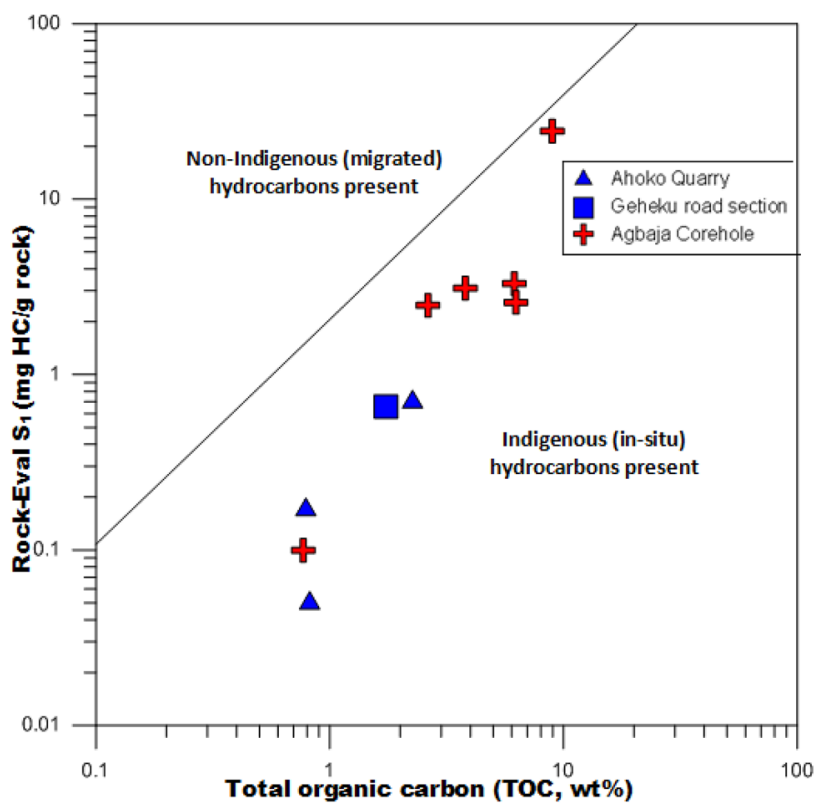

Fig. 13 Plot of S1 versus TOC for shale samples from Patti Formation, Bida Basin
Table 3 Maceral composition and vitrinite reflectance data from the analysed shales of the Patti Formation

\begin{tabular}{lllllll}
\hline S/N & Sample no & Liptinite & Vitrinite & Inertinite & $\begin{array}{l}\text { TAI (Staplain } \\
1969)\end{array}$ & $\begin{array}{l}\text { Vitrinite } \\
\text { reflectance } \\
\text { Ro (\%) }\end{array}$ \\
\hline 1 & AH1A & 70 & 25 & 5 & 2 & 0.46 \\
2 & AH1C & 15 & 80 & 5 & 2 & 0.47 \\
3 & AH4 & 35 & 60 & 5 & 2 & 0.48 \\
\hline
\end{tabular}


Table 4 Quantitative distribution of hydrocarbon extracts and some biomarker parameters from the investigated shale samples from the Patti Formation

\begin{tabular}{lllllllllllll}
\hline S/N & Sample code & Location & SAT (\%) & ARO (\%) & NSO (\%) & ASPH (\%) & PR/PH & Pr $/ \mathrm{n}_{\mathrm{C} 17}$ & $\mathrm{Ph} / \mathrm{n}_{\mathrm{C} 18}$ & $\mathrm{n}_{\mathrm{C} 18} / \mathrm{n}_{\mathrm{C} 19}$ & $\mathrm{n}_{\mathrm{C} 17} / \mathrm{n}_{\mathrm{C} 29}$ & $\mathrm{CPI}$ \\
\hline 1 & AH4 & Agbaja & 12.92 & 9.55 & 44.38 & 33.15 & 2.38 & 2.59 & 0.75 & 1.04 & 0.02 & 3.07 \\
2 & JAH1Q & Ahoko & 8.21 & 4.40 & 30.21 & 57.18 & 2.94 & 1.30 & 0.34 & 1.32 & 0.03 & 3.54 \\
\hline
\end{tabular}

if higher thermal maturity level is attained. At present level, pyrolytic yield is high in the source rock facies, but conversion is low and source beds are barely within oil window.
The predominance of Pristane $\left(n-\mathrm{C}_{17}\right)$ over Phytane $\left(n-\mathrm{C}_{18}\right)$ suggests humic origin for the organic matter in the source rocks and a swamp depositional environment. The organic matters were derived mainly from terrestrial/
Fig. 14 a Gas chromatography and biomarker diffractogram for Agbaja borehole sample quarry sample, Bida Basin. b Gas chromatography and biomarker diffractogram for Ahoko sample. Note the single peak denoting single source from higher plants and prevalence of heavy fractions
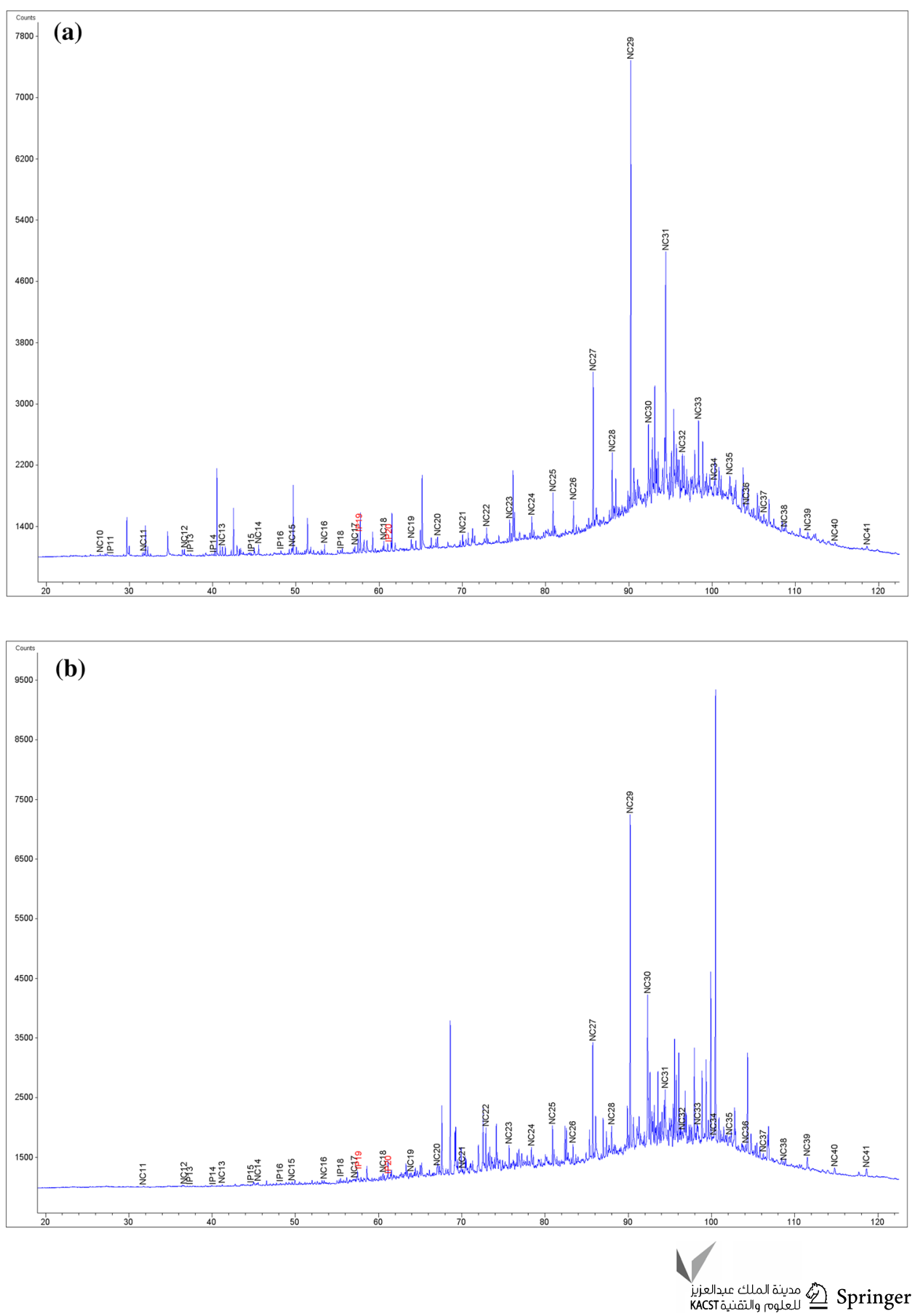
terrigenous plants under oxidizing condition. Reducing lacustrine environments is, however, probable in the Bida Basin.

Even though type III organic matter predominates, the study suggests that there is prospect for type II organic matter and lacustrine facies in the basin. The source rocks in the deeper subsurface level at projected to be at the onset of oil generating window. Perhaps the most revealing and significant of this study is the occurrence of shales with excellent source rock characteristics in the subsurface of Agbaja area of the basin reported for the first time in this paper.

Open Access This article is licensed under a Creative Commons Attribution 4.0 International License, which permits use, sharing, adaptation, distribution and reproduction in any medium or format, as long as you give appropriate credit to the original author(s) and the source, provide a link to the Creative Commons licence, and indicate if changes were made. The images or other third party material in this article are included in the article's Creative Commons licence, unless indicated otherwise in a credit line to the material. If material is not included in the article's Creative Commons licence and your intended use is not permitted by statutory regulation or exceeds the permitted use, you will need to obtain permission directly from the copyright holder. To view a copy of this licence, visit http://creativecommons.org/licenses/by/4.0/.

\section{References}

Adegoke AK, Abdullah WH, Hakimi MH, SarkiYandoka BM, Mustapha KA, Aturamu AO (2014) Trace elements geochemistry of kerogen in Upper Cretaceous sediments, Chad (Bornu) Basin, northeastern Nigeria: origin and paleo-redox conditions. J Afr Earth Sci 100:675-683

Adegoke AK, Abdullah WH, Hakimi MH (2015) Geochemical petrographic characterization of Fika shale succession in the Chad (Bornu) Basin, northeastern Nigeria: origin and hydrocarbon generation potential. Mar Pet Geol 61:95-110

Adeleye DR (1989) The geology of the middle Niger Basin. In: Kogbe CA (ed) Geology of Nigeria, 2nd edn. Elizabethan Publishing Co., Lagos, pp 283-287

Adeleye DR, Dessauvagie TFJ (1972) Stratigraphy of the Niger Embayment, near Bida, Nigeria. In: Dessauvagie TFJ, Whiteman AJ (eds) African geology. University of Ibadan Press, Ibadan, pp $181-185$

Agyingi CM (1993) Palynological evidence for a late Cretaceous age for Patti Formation, Eastern Bida Basin, Nigeria. J Afr Earth Sci 17:513-523

Akande SO, Ojo OJ, Erdtmann BD, Hetenyi M (2005) Paleoenvironments, organic petrology and Rock-Eval studies on source rock facies of the Lower Maastrichtian Patti Formation, southern Bida Basin, Nigeria. J Afr Earth Sci 41:394-406

Batten DJ (1983) Identification of amorphous sedimentary organic matter by transmitted light microscopy. In: Brooks J (ed) Petroleum geochemistry and exploration of Europe, vol 12. Blackwell Scientific Publications, Boston, pp 275-287

Batten DJ (1996) Palynofacies and palaeoenvironmental interpretation. In: Jansonius J, McGregor DC (eds) Palynology: principles and applications. American Association of Stratigraphic Palynologists (AASP), vol 3, pp 1011-1064

Bohacs KM, Carroll AR, Neal JE, Mankiewicz PJ (2000) Lakebasin type, source potential, and hydrocarbon character: an integrated-sequence-stratigraphic-geochemical framework. In: GierlowskiKordesch EH, Kelts KR (eds) Lake basins through space and time. AAPG Studies in Geology, vol 46, pp 3-34

Boltenhagen E (1978) Proteacidites sigalii, espèce nouvelle de pollen proteaceoide du senonien du Gabon. Revista Española Micropal 21(4):13-15

Braide SP (1992) Syntectonic fluvial sedimentation in the central Bida Basin. J Min Geol 28:55-64

Bustin RM, Cameron AR, Grieve DA, Kalkreuth WD (1983) Coal petrology-its principles, methods, and applications: Geological Association of Canada Short Courses Notes, 3, 230p

Couper RA (1953) Upper Mesozoic and Cainozoic spores and pollen grains from New Zealand. N Z Geol Surv Palaeontol Bull 22:1-77

Ehinola OA, Sonibare OO, Falana AM, Javie D (2005) Organic geochemistry and biomarker evaluation of shale units of the Patti Formation, Bida Basin, Nigeria. NAPE Bull 19(1):78-88

El Atfy H, El Diasty WSh, El Beialy SY, Gheith AM, Batten DJ, Agha NN (2017) Palynofacies and geochemical analyses of the upper Cretaceous-Eocene succession, western Sirte Basin, Libya: paleoenvironmental interpretation and implications for hydrocarbon generation potential. J Petrol Sci Eng 157:148-163

El Diasty WSh, El Beialy SY, Littke R, Farag FA (2016a) Source rock evaluation and nature of hydrocarbons in the Khalda Concession, Shushan Basin, Egypt's Western Desert. Int J Coal Geol 162:45-60

El Diasty WSh, El Beialy SY, Peters KE, El Atfy H, Gheith AM, Agha NN (2016b) Organic geochemistry of crude oils and Upper Cretaceous source rocks from Concession 11, west Sirte Basin, Libya. J Pet Geol 39:393-413

Erdtman G (1952) Pollen morphology and plant taxonomy. Angiosperms-an introduction to palynology, vol. I, Stockholm, Almqvist \& Wiksell, (Vol. II, 1953; Vol. III, 1965; Vol. IV, 1971)

Espitalie J, Deroo G, Marquis F (1985) Rock-eval pyrolysis and its application, 1st edn. Institute de France, Paris, p 72

Evitt WR (1969) Dinoflagellates and other organisms in palynological preparations. In: Tschundy RH, Scott RA (eds) Aspects of palynology. Wiley Interscience, New York, pp 439-481

Evitt WR, Lentin JK, Mlllioud, ME, Stover LE, Williams GL (1977) Dinoflagellate cyst terminology. Geol. Surv. Canada, Paper 76-24, $9 \mathrm{p}$

Fensome RA, Williams GL (2004) The Lentin and Williams Index of Fossil Dinoflagellates. 2004 Edition: 909 pp

Germeraad JH, Hopping CA, Muller J (1968) Palynology of Tertiary sediments from tropical areas. Rev Palaeobot Palynol 6:189-348

Helenes J, De Guerra C, Vasquez J (1998) Palynology and chronostratigraphy of the upper cretaceous in the subsurface of the Barinas area, Western Venezuela. AAPG Bull 82:1308-1328

Hunt JM (1996) Petroleum geochemistry and geology, 2nd edn. W.H. Freeman and Company, New York

Jain KP, Millepied P (1973) Cretaceous microplankton from Senegal Basin, N. W. Africa. 1. Some new genera species and combinations of diniflagellates. The Palaeobotanist 20(1):22-32

Jan Du Chene RE (1987) The dinoflagellate cysts from the danian of the madeleines formation, Dakar, Senegal: a systematic study. Cahiers De Micropaleonotlogie 2:3-4

Jan du Chene RE, Adegoke OS, Adediran SA, Petters SW (1979) Palynology and Foraminifera of the Lokoja Sandstone (Maastrichtian), Bida Basin Nigeria. Revista Espanola de Micropaleontologia 10(3):379-393

Jan Du Chêne RE, De Klasz I, Archibong EE (1978) Biostratigraphic study of the borehole Ojo-1, SW Nigeria, with special emphasis on the Cretaceous microflora. Rev Micropaléont 2:123-139

Jimoh AY, Ojo OJ (2016) Rock-Eval pyrolysis and organic petrographic analysis of the Maastrichtian coals and shales at Gombe, Gongola Basin, Northeastern Nigeria. Arab J Geosci 9:443 
Jones HA (1958) The Oolitic Ironstones of Agbaja Plateau, Kabba Province. Record of the Geological Survey of Nigeria 20-43

Kennedy WQ (1965) The influence of basement structure on the evolution of the coastal (Mesozoic and Tertiary) basins. In: Recent Basins around Africa, proceedings of the Institute of Petroleum Geologists Society London, pp 35-47

King LC (1950) Outline and distribution of Gondwanaland. Geol Mag 87(5):353-359

Kogbe CA, Ajakaiye DE, Matheis G (1983) Confirmation of Rift structure along the mid-Niger valley, Nigeria. J Afr Earth Sci $1: 127-131$

Ladipo KO, Akande SO, Mucke A (1994) Genesis of ironstones from the mid-Niger sedimentary basin: evidence from sedimentological, ore microscopic and geochemical studies. J Min Geol 30:161-168

Langford FF, Blanc-Valleron MM (1990) Interpreting Rock Eval pyrolysis data using graphs of pyrolyzable hydrocarbons versus total organic carbon. AAPG Bull 74:799-804

Lawal O, Moullade M (1986) Palynological biostratigraphy of Cretaceous sediments in the upper Benue Basin, N.E, Nigeria. Revue de Micropaleontologie 29:61-83

Lentin JK, Williams GL (1973) Fossil dinoflagellates: index to genera and species. Geol. Surv. Canada Pap. 73-42, 176 pp

Mackenzie AS, Patience RL, Maxwell JR, Vandenbroucke M, Durand B (1980) Molecular parameters of maturation in the Toarcian shales, Paris Basin, France-I. Changes in the configurations of acyclic isoprenoid alkanes, steranes, and triterpanes. Geochim Cosmochim Acta 44:1709-1721

Masron ThC, Pocock SAJ (1981) The classification of plant-derived particulate organic matter in sedimentary rocks. In: Brooks J (ed) Organic maturation studies and fossil fuel exploration. London-Academic Press, London, pp 145-161

Muller J (1968) Palynology of the Pedawan and Plateau Sandstone (Cretaceous - Eocene) in Sarawak Malaysia. Micropaleontology $14(1): 1-37$

Obaje NG, Wehner H, Scheeder G, Abubakar MB, Jauro A (2004) Hydrocarbon prospectivity of Nigeria's inland basins: from the viewpoint of organic geochemistry and organic petrology. AAPG Bull 87:325-353

Ojo SB (1984) Middle Niger Basin revisited: magnetic constraints on gravity interpretations. In: Abstract, 20th conference of the Nigerian mining and geosciences society Nsukka, pp 52-53

Ojo SB, Ajakaiye DE (1989) Preliminary interpretation of gravity measurements in the mid-Niger Basin area, Nigeria. In: Kogbe CA (ed) Geology of Nigeria, 2nd edn. Elizabethan Publishers, Lagos, pp 347-358

Ojo OJ, Akande SO (2003) Facies relationships and depositional environments of the upper Cretaceous Lokoja Formation in the Bida Basin, Nigeria. J Min Geol 39:39-48

Ojo OJ, Akande SO (2004) Palynological and palaeoenvironmental analyses of selected samples from Dukul and Jessu Formations, Yola Basin, Nigeria. NAPE Bull 17(1):70-76

Ojo OJ, Akande SO (2006) Sedimentological and palynological studies of the Patti formation, southeastern Bida basin, Nigeria: implications for paleoenvironments and paleogeography. NAPE Bull 19:61-77

Ojo OJ, Akande SO (2008) Microfloral assemblage, age and palaeoenvironment of the Upper Cretaceous Patti Formation, southeastern Bida basin, Nigeria. J Min Geol 44(1):71-78

Ojo OJ, Akande SO (2009) Sedimentology and depositional environments of the Maastrichtian Patti Formation, southeastern Bida Basin, Nigeria. Cretaceous Res 30:1415-1425

Ojo OJ, Kolawole AU, Akande SO (2009) Depositional environments, organic richness and petroleum generating potential of the Campanian to Maastrichtian Enugu Formation, Anambra basin, Nigeria. Pac J Sci Technol 10(1):614-627
Oloto IN (1987) Maastrichtian dinoflagellate cyst assemblage from the Nkporo shale on the Benin Flank of the Niger Delta. Rev Palaeobot Palynol 57:173-186

Peters KE, Cassa MR (1994) Applied source-rock geochemistry. In: Magoon LB, Dow WG (eds.), The Petroleum System-From Source to Trap, AAPG Bulletin 60: 93-120

Peters KE, Moldowan JM (1993) The biomarker guide. interpreting molecular fossils in petroleum and ancient sediments. Prentice Hall, New Jersey

Peters KE, Walters CC, Moldwan JM (2005) 2nd edition. The biomarker guide 1 (471 pp)

Powell AJ (1992) Dinoflagellates of the tertiary system. In: Powell AJ (ed) A stratigraphic index of dinoflagellate cysts. British Micropalaeontological Society, Publication Series, Chapman and Hall, London, pp 155-229

Powell TG, Boreham CJ, Smyth M, Russel N, Cook AC (1991) Petroleum source rock assessment in non-marine sequences: pyrolysis and petrographic analysis of Australian coals and carbonaceous shales. Org Geochem 17:375-394

Rahaman MAO, Fadiya SL, Adekola SA, Coker SJ, Bale RB, Olawoki OA, Omada IJ, Obaje NG, Akinsanpe OT, Ojog GA, Akande WG (2019) A revised stratigraphy of the Bida Basin, Nigeria. J Afr Earth Sci 151:67-81

Raine JI, Mildenhall DC, Kennedy EM (2011) New Zealand fossil spores and pollen: an illustrated catalogue. 4th edition. GNS Science miscellaneous series no. 4. Retrieved from: http://data.gns. cri.nz/sporepollen/index.htm

Ross NE (1949) On a Cretaceous pollen and spore bearing clay deposit of Scania (a preliminary report). Bull Soc Geol Inst Univ Uppsala $34: 25-42$

Salami MB (1983) Some late cretaceous and early tertiary pteridophytic spores from the southern Nigeria sedimentary basins. Rev Esp Micropale 15(2):257-272

Salami MB (1990) Palynomorph taxa from the "Lower Coal Measures" deposits (? Campanian-Maastrichtian) of Anambra Trough. Southeastern Nigeria J Afr Earth Sci 11(1/2):135-150

Salard-Cheboldaeff M (1981) Palynologie maestrichtienne et tertaire du Cameroun. Resultat botaniques Rev Palaeobot Palynol 32:401-439

Salard-Cheboldaeff M (1990) Intertropical African palynostratigraphy from Cretaceous to late quaternary times. J Afr Earth Sci 11:1-24

Samuel O, Cornford C, Jones M, Adekeye OA, Akande SO (2009) Improved understanding of the petroleum systems of the Niger delta basin, Nigeria. Org Geochem 40:461-483

Schrank E (1984) Organic-walled microfossils and sedimentary facies in the Abu Tartur phosphates (Late Cretaceous, Egypt). Berlin Geowiss. Abh (A) 50:177-187

Schrank E (1994) Palynology of the Yesomma Formation in northern Somalia: a study of pollen, spores and associated phytoplankton from the Late Cretaceous Palmae Province. Palaeontogr Abteilung B 231(63-112):1-15

Seifert WK, Moldowan JM (1980) The effect of thermal stress on source-rock quality as measured by hopane stereochemistry. Phys Chem Earth 12:229-237

Stach EM, Mackowsky MT, Teichmuller M, Taylor GH, Chandra D, Teichmuller R (1982) Stach's textbook of coal petrology. Borntraeger Verlag, Berlin, p 535

Staplain FL (1969) Sedimentary organic matter, organic metamorphism, and oil and gas occurence. Bull Can Petrol Geol 17:47-66

Sultan IZ (1985) Palynological studies in the Nubia Sandstone Formation, East of Aswan, Southern Egypt. N Jb Geol Palaont Mh 10:605-617

Thakur OP, Dogra NN (2011) Palynofacies characterization for hydrocarbon source rock evaluation in the Subathu Formation of Marhighat, Sirmaur district, Himachal Pradesh. Earth Syst. Sci. 120, No. 5, 933-938 Indian Academy of Sciences

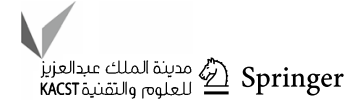


Tissot B, Durand B, Espitalie J, Combaz A (1974) Influence of the nature and diagenesis of organic matter in formation of petroleum. AAPG Bull 58(499):506

Tyson RV (1995) Sedimentary organic matter: organic facies and palynofacies. Chapman and Hall, London, p 615

Udensi EE, Osazuwa IB (2004) Spectra determination of depths to magnetic rocks under the Nupe Basin, Nigeria. NAPE Bull 17:22-37

Van Der Hammen T (1954) El desarrollo de la Flora Colombiana en los periodos geológicos. 1: Maestrichtiano hasta Terciario mas inferior. Bol Geol 2(1):49-106

Van der Hammen Th, Garcia de Mutis C (1965) The Paleocene flora of Colombia. Leidse Geol Meded 35:105-116
Van Hoeken-Klinkenberg PMJ (1964) A palynological investigation of some Upper Cretaceous sediments in Nigeria. Pollen Spores 6:209-231

Van Hoeken-Klinkenberg PMJ (1966) Maastrichtian Paleocene and Eocene pollen and spores form Nigeria. Leidse Geol Mededel $38: 37-48$

Publisher's note Springer Nature remains neutral with regard to jurisdictional claims in published maps and institutional affiliations. 